\title{
Mycoflora Associated with Stored Onion and their Cultural Characteristics
}

\author{
Lipilipsa Priyadarshinee $^{1 *}$, M. K. Mishra ${ }^{1}$, Debasish Pattnaik ${ }^{2}$, \\ Tensirani Pradhan ${ }^{1}$, Sandhyarani Nanda ${ }^{1}$ and Swagatika Babu' \\ ${ }^{1}$ Department of Plant Pathology, ${ }^{2}$ Department of Plant Physiology, \\ Odisha University of Agriculture and Technology, Bhubaneswar, 751003, Odisha, India \\ *Corresponding author
}

\section{A B S T R A C T}

\begin{tabular}{|l|}
\hline $\begin{array}{l}\text { Ke y w or d s } \\
\text { Mycoflora,Stored } \\
\text { onion,cultural } \\
\text { characteristics }\end{array}$ \\
\hline Article Info \\
\hline $\begin{array}{l}\text { Accepted: } \\
\text { 05 June 2020 } \\
\text { Available Online: } \\
\text { 10 July 2020 }\end{array}$ \\
\hline \hline
\end{tabular}

Onion being important vegetable crop grown in India is preferred mainly because of its green leaves, immature and mature bulbs which are either eaten raw or cooked as a vegetable. Post-harvest losses due to desiccation, decay and sprouting possess a great threat for effective economic use of onion. Infected large and small sized onions (495 numbers) were collected from different market places of Bhubaneswar, Odisha for association of fungal mycoflora. Out of these Aspergillus niger, Fusarium oxysporum and Botrytis sp were found to be associated with 214,169 and 112 number of rotted samples of both large and small sized onion samples respectively. Whitish black rotten areas with blackish powdery masses and water soaked patches on the skin were found on different size of onion. Whitish fungal growth of F.oxysporum was found in Potato dextrose agar (PDA) which turned pink colour after seven days of inoculation and its conidia measured to $18.39-25.63 \times 3.58$ $4.93 \mu \mathrm{m}$. Green white mycelium was developed on the petridish by Botrytis $s p$. and measured 7.77 $\times 4.58 \mu \mathrm{m}$. Mycelium of A.niger was submerged, hyaline, septate and complete black colouration on Potato Dextrose Agar (PDA). Vesicle measured 55-85 $\mu \mathrm{m}$. Potato Dextrose Agar (PDA) medium supported highest growth of F.oxysporum $(80.13 \mathrm{~mm})$ followed by Richard's agar $(76.63 \mathrm{~mm})$. Potato Rose Bengal Agar supported least growth $38.23 \mathrm{~mm}$. PDA also supported highest radial growth of A.niger $(81 \mathrm{~mm})$. The growth of F.oxysporum increased from $15^{\circ} \mathrm{C}$ reaching maximum at $25^{\circ} \mathrm{C}$ $(82.25 \mathrm{~mm})$ and declined thereafter with minimum in $35^{\circ} \mathrm{C}(64.75 \mathrm{~mm})$.

\section{Introduction}

Onion (Allium cepa L.) is one of the oldest bulb crops, known to mankind. It is one of the most important vegetable crops grown in India and believed to be originated in Central Asia. Onion is preferred mainly because of its green leaves, immature and mature bulbs which are either eaten raw or cooked as a vegetable. It is valued because of its distinct pungent flavour and is an essential ingredient for the cuisine of many regions (Kukanor,
2005). Despite of availability of good varieties of onion and achievement in production technology, the post-harvest losses during storage is still an ailing cause which leads to significant quantitative and qualitative losses during storage upto 25-30 $\%$.

Onion is susceptible to numerous foliar, bulb and root pathogen that ultimately reduce yield and quality. It is attacked by several fungal, bacterial, and viral diseases among which 
Fusarium oxysporumf. sp. cepae, Botrytis cinerea and Aspergillus niger are important. Onion is known to get infected with Fusarium oxysporumf. sp. cepae causing basal bulb rot of onion, which caused considerable damage to onion bulb(Patil, 2012). The disease is characterized by wilting and rapid dying back of leaves from the tips of the plants near maturity.

Infected plants can be pulled out easily because they have a retarded root system (Ilhe et al., 2013).Several Allium crop diseases are also affected by Botrytis spp, which results in yield losses in different parts of the world. Botrytis cinerea causes leaf fleck, blight and is the causal agent of neck rot (Droby et al., 2007, Wright et al., 2001). Aspergillus niger is one of the important storage infectant of onion bulb. It has highest percentage frequency of occurrence in onion. The percentage of their frequency is 50.3 (Khatoon et al., 2017). In view of this an investigation was conducted for association of any fungal flora among stored onion in Bhubaneswar township. The detailed study of decay fungi associated with stored onion were conducted in Plant Pathology Department, College of Agriculture, Odisha University of Agriculture and Technology, Bhubaneswar, Odisha.

\section{Materials and Methods}

\section{Collection of infected samples}

Rot affected onion bulbs exhibiting black, sunken and water soaked lesions were collected from different market places of Bhubaneswar. Infected samples were brought to the laboratory and microscopically observed for associated pathogen. These were surface sterilized and kept in a moist chamber aseptically for about 72 hours so as to develop the fungal colonies. Microscopic examination of fungal growth were conducted.

\section{Isolation of pathogen}

The infected onion sample having both healthy and diseased portion were sterilized using 1\% sodium hypochlorite for 3-4 minute. These were washed 3 times with sterilized distilled water. These portions were transferred to plate containing solidified potato dextrose agar(PDA) medium.

sThe observations were taken periodically after incubation at $27 \pm 1^{\circ} \mathrm{C}$. Colony of fungal mycelium was found on plates after seven days of plating. Hyphal tip method was followed for preparing the pure culture of all associated fungal mycoflora.

\section{Pathogenicity test}

Healthy onion samples were collected from different markets of Bhubaneswar, Odisha. Healthy onions were washed thoroughly with tap water followed by distilled water. These were surface disinfected with $95 \%$ ethyl alcohol. Fungal discs of each isolated pure culture were inserted in the holes made with the help of cork borer in healthy onion and kept on laboratory table for initiation of symptoms.

\section{Cultural characteristics}

The cultural characteristic of the causal pathogen were studied using different media. Media like Czapek's dox agar medium,Potato rose Bengal agar medium, Richards agar medium, Malt extract agar medium, Sabouraud's agar medium, Brown's agar medium and Potato dextrose agar medium were prepared using standard protocol and was sterilized in the autoclave at $15 \mathrm{psi}$ pressure for 20 minute.

The radial growth of causal pathogen was carried out in temperature ranges like $15^{\circ} \mathrm{C}$, $20^{\circ} \mathrm{C}, 25^{\circ} \mathrm{C}, 30^{\circ} \mathrm{C}, 35^{\circ} \mathrm{C}$ using incubator. 


\section{Results and Discussion}

\section{Collection of infected onion sample}

The infected onion bulbs showing symptoms of rotting were collected from different places of Bhubaneswar. A total no of 495 infected samples (316 number large sized and 179 number of small sized) exhibiting black, sunken, water soaked lesions were brought to the laboratory and microscopically observed for associated pathogen (Table 1).

\section{Symptomatology}

\section{Fusarium oxysporum}

Whitish black rotten areas were found at the tip to downward with foul smell. The tips of the large onion were found to be depressed. Faint black rotting areas were found on the skin of the small onion. The extents of rotting on the large onion were more than that of small onion. Sumner (1995 a, b) reported brown colouration with watery appearance in Fusarium oxysporum infected bulb. Soft rot and semi water symptoms on onion bulb infected with Fusarium oxysporum were also reported by Fageria et al., (2003).

\section{Aspergillus niger}

Healthy samples were completely free from diseases with red colour skin but in infected bulb, red colour of skin was completely absent due to black spore coverage. Blackish powdery masses were found on the surface of large onion which could be rubbed off easily.

Small sized onions were also found to be infected by blackish spore mass from the tip downward. Walker (1952) also noted that in case of black the black powdery masses of spores were borne on exterior of the scales and can be rubbed off readily. Tiwari et al., (1984), Singh, (1995) also reported that invaded tissue becomes water soaked at first and a white mold develops between the scales, soon produced black spores.

\section{Botrytis species}

Large onions were found to be rotting from the tip with black coloration and water soaked patches on the skin of the onion. Very small whitish fungal growths were observed on the blackish rotten area at the tip of the onion.

Faint whitish fungal growths were also found on small onion without any rotting area. Elad et al., (2007) reported Botrytiscinerea causing neck rot in onion. Fillinger et al., (2016) reported neck rot caused by Botrytis cinerea was destructive pathogen of stored onion.

\section{Pathogenicity test}

\section{Fusarium oxysporum}

Pure culture of $F$. oxysporum were grown for 7 days and inoculated with cork borer method to both large and small sized onion. Onion bulbs were completely damaged in 10 days after inoculation. The internal tissues were rotted, putrified by the fungus and upon re isolation, the same fungus was isolated.

Christopher (2000) and Behrani et al., (2015) proved pathogenicity by inoculating the seedling of onion and by soil inoculation method.

\section{Aspergillus niger}

Inoculated onions of both large and small sized were completely rotted within 10 days of inoculation. On splitting large onion after 10 days, rotted putrifying tissues with blackish colouration was found. Upon isolation the same fungus was isolated. Ara et al., (2008) proved pathogenicity by inoculating the seedling of onion. 


\section{Botrytis species}

Inoculated onions of both large and small sized were completely rotted within 10 days of inoculation. On splitting large onion after 10 days, rotten faint whitish colouration was found. Upon isolation the same fungus was isolated.

\section{Mycoflora associated with stored onion}

Infected samples were observed under microscope for the association of microorganism. The detailed association of microorganism with the samples collected from different market were described below. A total number of 316 large sized samples were evaluated and out of that 141 samples were associated with $A$. niger followed by $F$. oxysporum (107) and Botrytis sp.(68). In small onion also maximum samples were associated with $A$. niger (73), $F$. oxysporum(62), $B$. cineria(44)(Table 2).

\section{Fusarium oxysporum}

Whitish fungal growths present on the infected onion were observed under microscope. Mycelial beads were taken to potato dextrose agar (PDA) aseptically grown for 7 days and again purified by fungal tip method. Cottony whitish growth was observed on the PDA plate turning to slightly pink colour after 7 days of inoculation. The growth of the fungus also became completely white and turned to pink colour. Sporodochia consisted of branched conidiophore. The aerial mycelium appeared white and changed to pink colour afterwards.

The mycelium was extensive intra and inter cellular. Macro conidia are grown in sporodichia. They are mostly long, slender, pointed at both the ends, dorso ventrally curved, sickle cell, septate. The conidia was measured and varied from $18.39-25.63 \times 3.58$ -
$4.93 \mu \mathrm{m}$. The fungus was identified as F.oxysporum. Micro conidia were also observed in the culture. They are usually one celled, oval shaped. Chlamydospores were also observed in the culture which were characterized by the appearance of thick rounded double layer dark spots found in chains and measured $5.16 \mu \mathrm{m}$ as shownin Fig $1(\mathrm{a}, \mathrm{b})$.

Brayford (1996), Kawade et al., (2012) and other workers reported presence of macro, micro conidia and chlamydospore in $F$. oxysporum culture. Patra and Biswas (2016) also reported conidial size ranging from 13-15 x 2-3 $\mu \mathrm{m}$ to $15-19 \times 3-4 \mu \mathrm{m}$ in culture of Fusarium oxysporumf. sp. cicero. In the current study thick round double layer dark chlamydospores also observed in chains measuring $5.16 \mu \mathrm{m}$ in old culture of Fusarium oxysporum. Cramer (2000) also reported the existence of chlamydospores in old mycelia as half round cell with thick cell wall which confirmed the finding of the current study.

\section{Botrytis species}

Infected onion bulbs developed semi watery starting from neck region, grey white mycelia were developed on the petridish. The fungus covered in entire plate within 8 days of inoculation. Abundant short conidiophores about $1 \mathrm{~mm}$ long were found. Conidia were round to oval, single celled and measured as $7.77 \times 4.58 \mu \mathrm{m}$ as shown in Fig $2(\mathrm{c}, \mathrm{d})$. The fungus was identified as Botrytis $s p$. as per the available literature. This was also reported by Nielsen et al., (2001) who has found white fluffy mycelium and sparse production of conidia by Botrytis sp. Shirane et al., (1989) reported two groups of spore size of Botrytis allii of onion i.e 10- $11 \mu \mathrm{m} \times 5-6 \mu \mathrm{m}$, and the other $8-9 \mu \mathrm{m} \quad \mathrm{x} \quad 4-5 \mu \mathrm{m}$. The current measurement was confirmed by the above one. 


\section{Aspergillus niger}

The blackish sporulation found on the infected onion was transferred to PDA and pure culture was prepared. Colonies of PDA were found to be faint white and gradually changed to black colour due to aerial sporulation by the fungus. Mycelium was submerged hyaline and septate. Conidiophores arised on the mycelium were yellow brown near the head, thick walled, mostly non septate. Conidial heads were brown to black, globose forming a vesicle and measured 55-85 $\mu \mathrm{m}$ in diameter. Phialedes were born directly and conidia were found in chains.
The conidia were round, smooth at first and later turned to serrated impacting rough appearance to the outer peripheral wall as shown in Fig 3 (e,f). The fungus was identified as $A$. niger according to the available literature. Alexopoulous (1952) and Walker (1952) described A.niger associated with onion having continuous dark walled spherical conidia $2-5 \mu \mathrm{m}$ in diameter born in chains.

In the current study, conidia are present in chains on the black globose vesicle measuring $55-85 \mu \mathrm{m}$. The conidia were found as round and serrated with rough appearance with outer peripheral wall.

Table.1 Collection of infected onion sample from different market places

\begin{tabular}{|c|c|c|c|}
\hline SI. No & Name of market places & \multicolumn{2}{|c|}{ No of infected samples } \\
\cline { 3 - 4 } of Bhubaneswar & Large size onion & Small size onion \\
\hline $\mathbf{1}$ & No 1 market & 82 & 75 \\
\hline $\mathbf{2}$ & Delta square market & 58 & 26 \\
\hline $\mathbf{3}$ & Siripur market & 80 & 15 \\
\hline $\mathbf{4}$ & Ruchika market & 96 & 63 \\
\hline & Total & 316 & 179 \\
\hline & Grand total & & \\
\hline
\end{tabular}

Table.2 Microscopic observation of different infected samples collected

\begin{tabular}{|c|c|c|c|c|c|c|c|c|c|}
\hline \multicolumn{10}{|c|}{ No of infected samples collected } \\
\hline \multirow[b]{2}{*}{$\begin{array}{c}\text { Sl } \\
\text { No }\end{array}$} & \multirow[b]{2}{*}{$\begin{array}{c}\text { Name of the } \\
\text { market } \\
\text { place of } \\
\text { Bhubaneswar }\end{array}$} & \multicolumn{4}{|c|}{ Large size onion } & \multicolumn{4}{|c|}{ Small size onion } \\
\hline & & $\begin{array}{c}\text { Total no } \\
\text { of } \\
\text { samples }\end{array}$ & $\begin{array}{c}\text { Botrytis } \\
\text { sp. }\end{array}$ & $\begin{array}{c}\text { Fusarium } \\
\text { oxysporum }\end{array}$ & $\begin{array}{c}\text { Aspergillus } \\
\text { niger }\end{array}$ & $\begin{array}{c}\text { Total no } \\
\text { of } \\
\text { samples }\end{array}$ & $\begin{array}{c}\text { Botrytis } \\
\text { sp. }\end{array}$ & $\begin{array}{c}\text { Fusarium } \\
\text { oxysporu } \\
m\end{array}$ & $\begin{array}{c}\text { Aspergillus } \\
\text { niger }\end{array}$ \\
\hline 01 & Unit 1 & 82 & 11 & 23 & 48 & 75 & 15 & 18 & 42 \\
\hline $\mathbf{0 2}$ & Delta square & 58 & 7 & 21 & 20 & 26 & 06 & 11 & 9 \\
\hline $\mathbf{0 3}$ & Siripur & 80 & 16 & 26 & 38 & 15 & 4 & 6 & 5 \\
\hline 04 & Ruchika & 96 & 27 & 34 & 35 & 63 & 19 & 27 & 17 \\
\hline & Total & 316 & 68 & 107 & 141 & 179 & 44 & 62 & 73 \\
\hline
\end{tabular}


Table.3 Growth behaviour of Fusarium oxysporum in different media 7 days after inoculation

\begin{tabular}{|c|c|c|c|}
\hline Treatment & Different solid media & $\begin{array}{c}\text { Mean colony } \\
\text { diameter }(\mathbf{m m})\end{array}$ & $\begin{array}{c}\text { Percent inhibition } \\
\text { in comparison to } \\
\text { PDA }\end{array}$ \\
\hline T1 & Potato dextrose agar & 80.13 & 0.0 \\
\hline T2 & Brown's agar & 70.20 & 12.39 \\
\hline T3 & Czapek'sdox agar & 68.20 & 14.8 \\
\hline T4 & Sabouraud's agar & 74.00 & 7.65 \\
\hline T5 & Richard's agar & 76.63 & 4.36 \\
\hline T6 & Potato rose Bengal agar & 38.23 & 52.29 \\
\hline T7 & Malt extract agar & 54.80 & 31.61 \\
\hline & SE(m) & 1.713 & \\
\hline & CD $(5 \%)$ & 5.247 & \\
\hline
\end{tabular}

Table.4 Growth behaviour of Aspergillus niger in different media 5 days after inoculation

\begin{tabular}{|c|c|c|c|}
\hline Treatment & Different solid media & $\begin{array}{c}\text { Mean colony } \\
\text { diameter }(\mathbf{m m})\end{array}$ & $\begin{array}{c}\text { Percent inhibition as } \\
\text { compared to PDA }\end{array}$ \\
\hline T1 & Czapekdox agar & 56.66 & 30.05 \\
\hline T2 & Malt extract agar & 55.00 & 32.10 \\
\hline T3 & Brown's agar & 52.01 & 35.79 \\
\hline T4 & Richard's agar & 71.66 & 11.53 \\
\hline T5 & Sabouraud's agar & 61.00 & 24.69 \\
\hline T6 & Potato rose Bengal agar & 61.00 & 24.69 \\
\hline T7 & Potato dextrose agar & 81.00 & 0.00 \\
\hline & SE(m) \pm & 2.031 & \\
\hline & CD $(5 \%)$ & 6.22 & \\
\hline
\end{tabular}

Table.5 Radial growth of Fusarium oxysporum in different temperature ranges

\begin{tabular}{|c|c|c|}
\hline Sl. No & Temperature $\left({ }^{\circ} \mathbf{C}\right)$ & Mean radial growth $(\mathbf{m m})$ \\
\hline $\mathbf{1}$ & 15 & 62.0 \\
\hline $\mathbf{2}$ & 20 & 62.0 \\
\hline $\mathbf{3}$ & 25 & 82.25 \\
\hline $\mathbf{4}$ & 30 & 74.0 \\
\hline $\mathbf{5}$ & 35 & 64.75 \\
\hline & & \\
\hline & SE (m) & 1.77 \\
\hline & CD 5\% & 5.41 \\
\hline
\end{tabular}




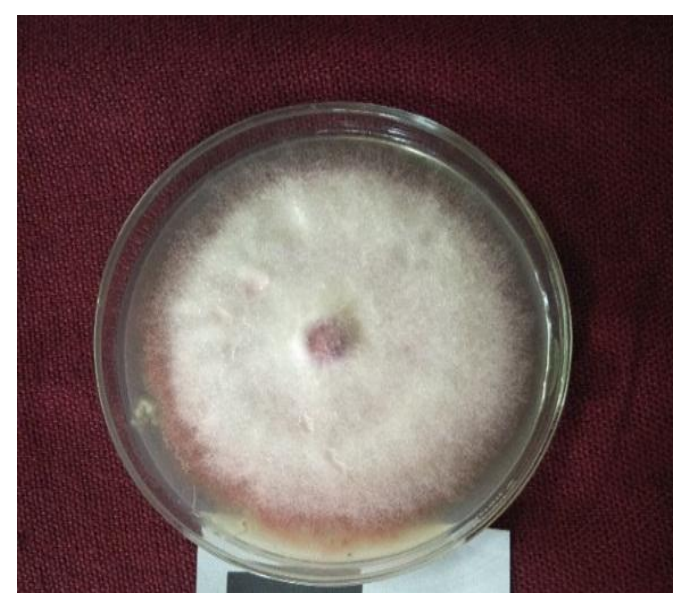

Fig.a

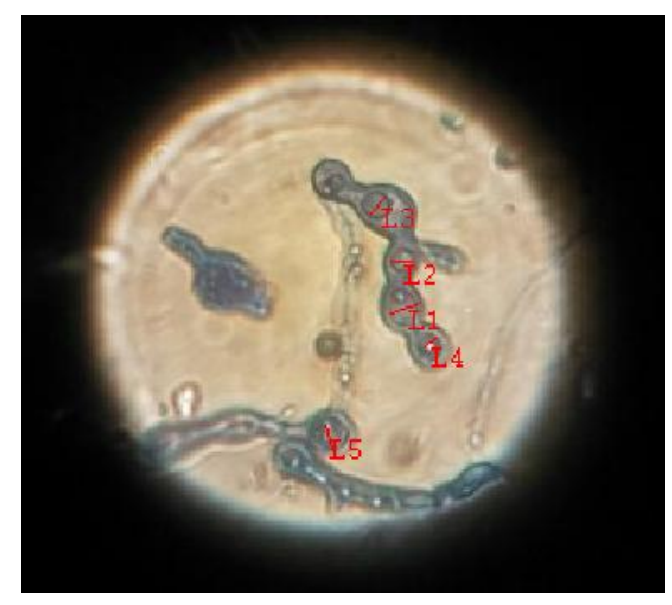

Fig.b

Fig.1 (a) Pure culture of Fusarium oxysporum plate and (b) Microscopic View of Fusarium oxysporum

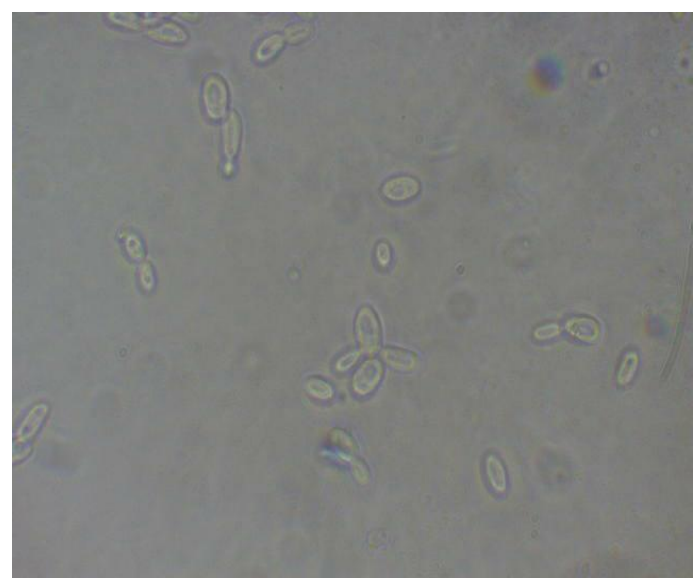

Fig.c (40x)

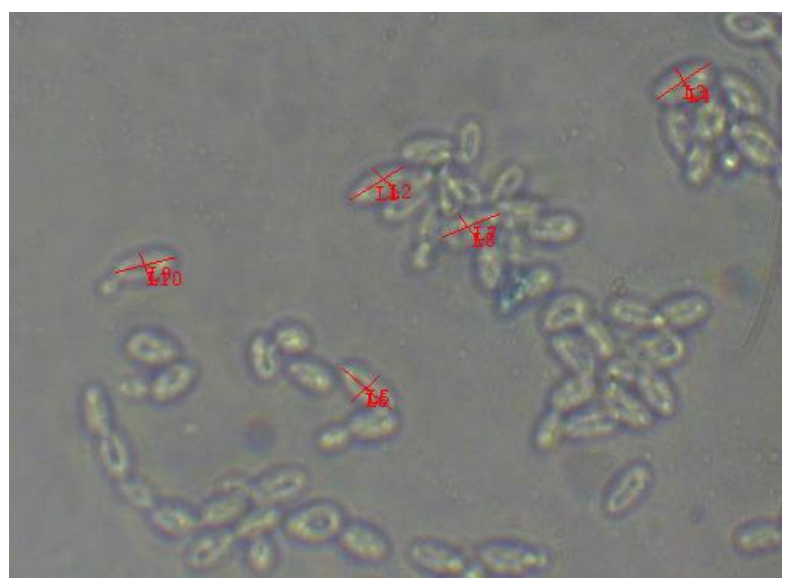

Fig.d (100x)

Fig.2 Microscopic View of Botrytis species (Fig c, d)

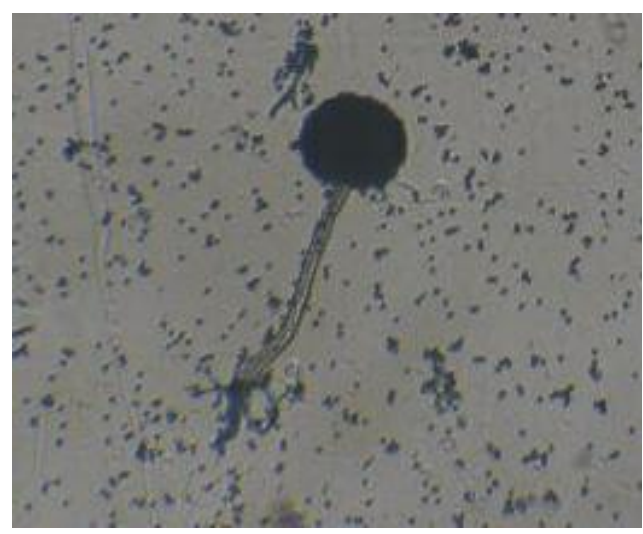

Fig.e (10x)

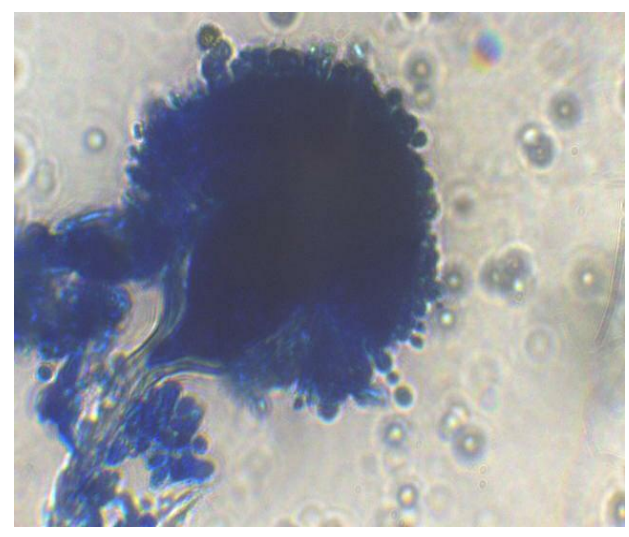

Fig.f (100x)

Fig.3 Microscopic view of Aspergillus niger (Fig e,f) 


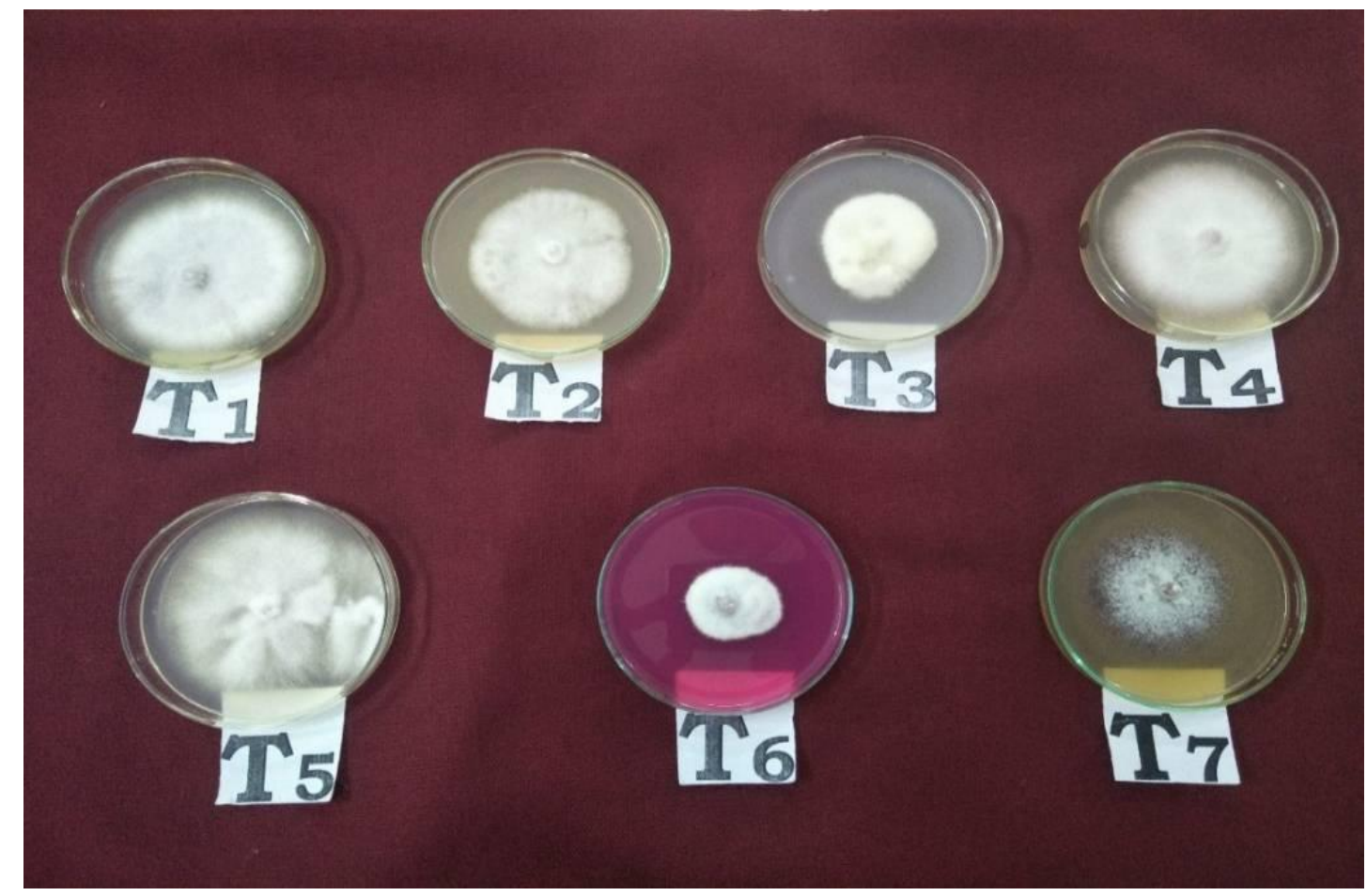

Fig.4a Growth behaviour of Fusarium oxysporum in different media T1: PDA, T2: Brown's Agar, T3: Czapek’s Agar, T4: Sabouraud's Agar, T5: Richard's agar, T6: Rose Bengal agar, T7: Malt extract agar

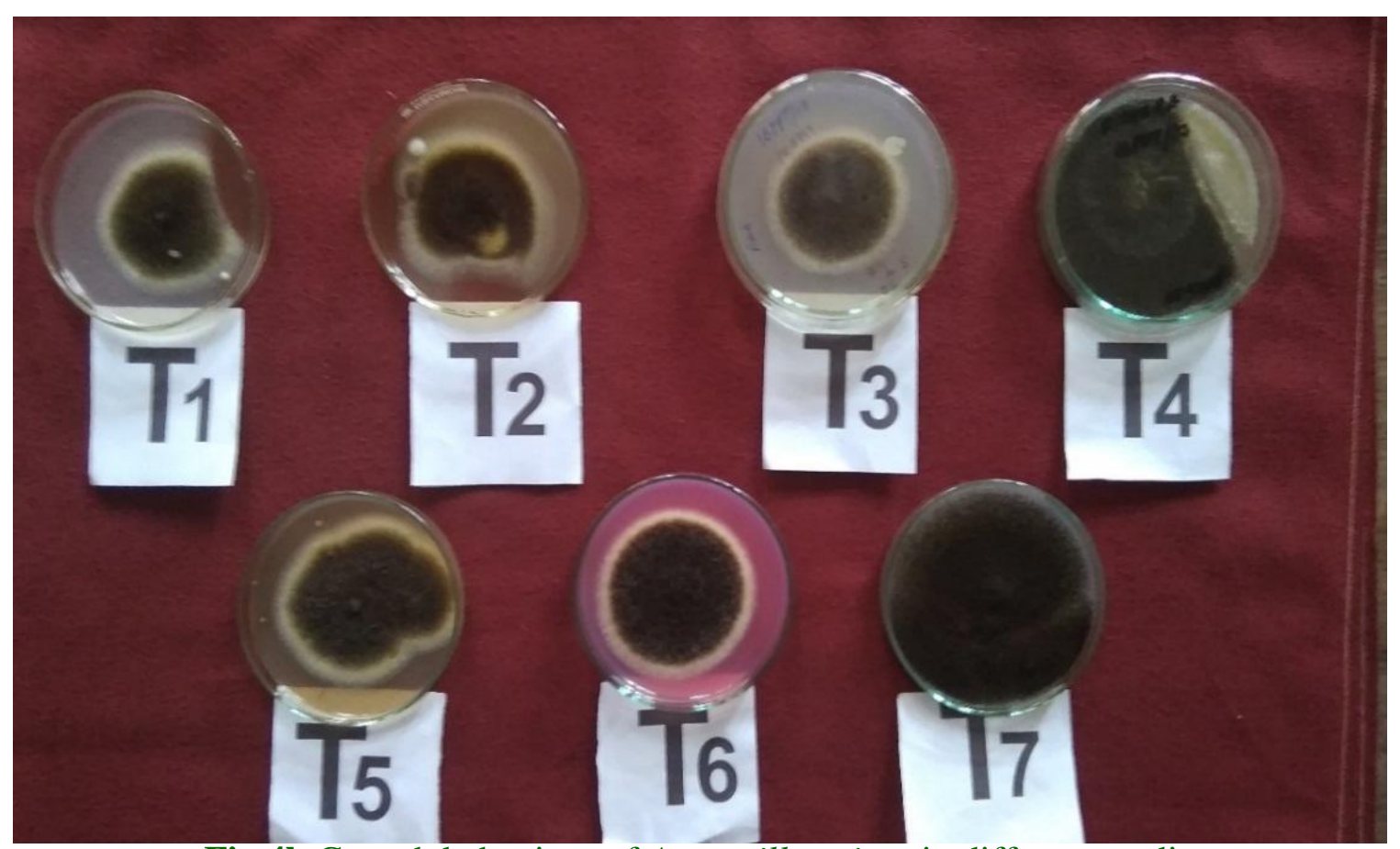

Fig.4b Growth behaviour of Aspergillus niger in different media

T1: Czapek's Agar, T2: Malt Extract Agar, T3: Brown's Agar, T4: Richard's Agar, T5: Sabouraud's Agar, T6: Potato Rose bengal Agar, T7: PDA 


\section{Cultural study}

Growth behaviour of test pathogen in different media

\section{F.oxysporum}

A total number of seven media were evaluated for the growth of test pathogen F.oxysporum. Significant radial growth was observed among all the media. Highest growth was observed in PDA $(80.13 \mathrm{~mm})$ followed by Richard's agar $(76.63 \mathrm{~mm})$ which was at par of PDA.

Sabouraud's agar $(74.00 \mathrm{~mm})$ also behaved similarly for the growth of F.oxysporum whereas potato rose Bengal supported the least growth $(38.23 \mathrm{~mm})$ (Table 3).Ilhe et al., (2013) found excellent growth of F.oxysporum f.sp. cepae in PDA followed by host leaf extract.

Other workers like Pokhar and Thakore (2003), Kulkarni,(2005) and Sharma et al., (2012) also found PDA as best growth medium for $F$. oxysporumf.sp. gladioli \& F.oxysporum f. sp. Lycopersici respectively.

\section{Aspergillus niger}

Significant difference were also observed in all the growth media by A.niger with PDA showing highest radial growth $(81 \mathrm{~mm})$ followed by Richard's Agar (71.66 mm). Sabouraud's agar and Potato rose Bengal were found to be same $(61 \mathrm{~mm})$ for the growth of A.niger (Table 4).

Prakash and Siradhana (1978) reported maximum growth in PDA followed by Richard's agar media. The current study of Richard's agar media was $71.66 \mathrm{~mm}$ radial growth which was next to PDA. Pathak (1993) reported better growth of A.nigerin Richard's solution followed by PDA.
Growth behaviour of F.oxysporum in different temperature ranges

The test pathogen showed highest radial growth of $82.25 \mathrm{~mm}$ in $25^{\circ} \mathrm{C}$ followed by in $30^{\circ} \mathrm{C}(74.00 \mathrm{~mm})$. The radial growth of the fungus increased from $15^{\circ} \mathrm{C}$ upto $25^{\circ} \mathrm{C}$ and then declined when temperature increased (Table 5).Similar observations were reported by Sharma et al., (2012), Chaturvedi et al., (2003) which confirmed the findings of current study. Gupta et al., (2010) and Mishra et al., (2010) reported maximum growth of F.oxysporumat $28^{\circ} \mathrm{C}$ followed by $34^{\circ} \mathrm{C}$.

\section{References}

Alexopoulos CJ. 1952. Introductory mycology. John Wiley and Sons, Inc., New York London, publication, pp:482.

Ara MAM, Khatun ML and Ashrafuzzaman M. 2008. Fungi causingrots in onions at storage and market, Journal Bangladesh Agricultural University6(2):245-251.

Behrani GQ, Syed RN, Abro MA, Jiskani MM and Khanzada MA. 2015. Pathogenicity and chemical control of basal rot of onion causedby Fusarium oxysporumf. sp. cepae. Pakistan Jouranal Agriculture, Agril. Engg.,Vet.Sci, 31(1): 60-70.

Brayford D .1996. IMI description of fungi and bacteria, set 127, No. 1263 Fusarium oxysporum f. sp. Cepae, Mycopathologia, 133: 39-40.

Chaturvedi VC, Gupta S, Gupta R and Shukla DN. 2003. Effect of temperature on growth and sporulation of some Fusarium species. Bioved, 14 : 33-35.

Christopher SC. 2000. Breeding and genetics of Fusarium basal rot resistance in onion, Euphytica, 115: 159-166

Cramer CS. 2000. Breeding and genetics of Fusarium basal rot resistance in onion. Euphytica Kluwer Academic publishers, 115: $159-166$ 
Droby S, Lichter A. 2007. Post-harvest Botrytis infection: Etiology, development and management, Elad $Y$. et al., (ed.) Botrytis, Biology, Pathology and Control, 2nd ed., Springer, Dordrecht, The Netherlands, 67: 349367.

Elad Y, Williamson B, Tudzynski $\mathrm{P}$ and Delen N. 2007. Botrytis spp. and diseases they cause in agricultural systems-an introduction, In Botrytis: Biology, pathology and control pp. 1-8.

Fageria MS, Choudhary BR and Dhaka RS. 2003. Production technology of vegetable crops, vol. II Kalyani Publishers, Ludhiana, pp. 56: 111-125.

Fillinger S, Elad Y. 2016. Botrytis - the Fungus, the Pathogen and its Management in Agricultural Systems, Springer International Publishing $A G$, 478: 90-95.

Gupta, VK, Misra AK, and Gaur RK. 2010. Growth characteristics of Fusarium spp. Causing wilt in Psidiumguajava $L$. in India, Journal of Plant Protection, 50: 452-462.

Ilhe BM, Musmade NA, Kawade SB. 2013.Studies on basal bulb rot of onion caused by Fusarium oxysporumf.sp.cepae, International journal of plant protection, 6 (2): 364366.

Kawade SB. 2012. Studies on basal bulb rot of onion (Allium cepa L.), M.P.K.V.Rahuri, 56: 30-33.

Khandar RR, Kapadiya HJ. 2006. Post harvest management of Black mold of onion (Allium cepaL.) caused by Aspergillus niger $V$. Tiegh, Thesis submitted to Junagadh Agricultural University, 56: 89-90.

Khatoon A, Mohapatra A, Satpathy KB. 2017. Studies on fungi associated with storage rot of onion (Allium cepa L.) and garlic (Allium sativum L.) bulbs in Odisha,India, International research journal biological science, 6 (1): 19-24. Kukanor L. 2005.Post harvest studies in onion Cv.N-53, Thesis submitted to the University of agricultural science, Dharwad, 12:78-80.

Kulkarni SP. 2005. Studies on Fusarium oxysporumSchlechtFr $f$. sp. gladioli (Massey) Snyd. \&Hans.causing wilt of gladiolus, M. Sc. (Agri.) Thesis, Univ. Agric. Sci. Dharwad, Karnataka (India), 67: 42-76.

Mishra AK, Gupta VK, Gaur RK, Jain PK and Sharma S .2010. Current status of Fusarium wilt disease of guava (Psidiumguajava L.) in India, Biotechnology, 9(2): 176-195.

Nielsen, K., Yohalem, D.S. and Jensen, D.F., 2002. PCR detection and RFLP differentiation of Botrytis species associated with neck rot of onion. Plant Disease, 86(6), pp.682-686.

PathakDM. 1993. Investigation on (Aspergillus niger Van Tieghem) with special reference to synthesis of oxalic acid and bioassay of pesticides, M.Sc. Thesis submitted to Gujarat Agricultural University, Sardarkrushinagar, Gujurat, pp:56-57

Patil MA .2012. Studies on onion basal rot caused by Fusarium oxysporum Schlecht f.sp.cepae, Thesis submitted to the University of Agricultural science, Dharwad, 07: 67-68.

Patra S and Biswas MK .2016. Studies on cultural, morphological and pathogenic variability among the isolates of Fusarium oxysporum $f$. sp.Cicero causing wilt of chickpea, International Journal of Plant, Animal and Environmental Sciences, 7(1): 11-16.

Pokhar R and Thakore BBL. 2003. Investigation on Fusarium rot of sponge gourd fruits. Journal of Mycology and Plant pathology, 33: 15-20.

Prakash O and Siradhana BS. 1978. Effect of temperature, $\mathrm{pH}$ and some media on 
four Aspergillusspp. isolated from maize grains, IndianPhytopath., 31(4):545-547

Sharma BK, Singh RP, Saha S, Kumar AB. 2012. Effect of temperature, $\mathrm{pH}$ and media on the growth and sporulation of Fusarium oxysporum $f$. sp. lycopersici causing wilt of tomato, Progressive Horticulture,43 (2) : 186-192.

Shirane, N., Masuko, M. and Hayashi, Y., 1989. Light microscopic observation of nuclei and mitotic chromosomes of Botrytis species. Phytopathology, 79(7), pp.728-730.

Singh RS. 1995. Disease of vegetable crops, 3rd ed. RajuPrimlani for Oxford and IBMPublishing Comp. New Delhi, p. 406:67-70.
Sumner DK. 1995. Fusarium basal plate rot, In: Compendium of onion and garlic disease .Eds. H. F. Schwart and S. K. Mohan., American Phypathological Society St. Paul. Minn, pp:10-11.

Tiwari BK, Srivastava KJ and Qadri SMH. 1984. Aspergillus niger: A Potent Enemy of Onions, Seed and Farm, 12:15-16.

Walker JC. 1952. Disease of vegetable crops,McGraw Hill Book Co., New York, pp: 529.

Wright PJ, Grant DG, Triggs CM. 2001. Effects of onion (Allium cepa) plant maturity at harvest and method of topping on bulb quality and incidence of rots in storage, New Zealand Journal CropHorticultural Science, 29:2, 85-91.

\section{How to cite this article:}

Lipilipsa Priyadarshinee, M. K. Mishra, Debasish Pattnaik, Tensirani Pradhan, Sandhyarani Nanda and Swagatika Babu. 2020. Mycoflora Associated with Stored Onion and their Cultural Characteristics. Int.J.Curr.Microbiol.App.Sci. 9(07): 418-428. doi: https://doi.org/10.20546/ijcmas.2020.907.047 